\title{
Identification of Entrepreneurship Opportunities and Exploitation
}

Bayram BALCI *

\begin{abstract}
Aim: it aims to identify the concept of entrepreneurship and to measure perception of entrepreneurship with university students such as entrepreneurship, opportunities of entrepreneurship, incentives of entrepreneurship, and training.

Method: A qualitative research was done in this study, and 32 students were interviewed. Interviews were conducted with a total of four subjects of students, and eight students have been selected from each division.

Findings: As a result of research carried out some basic problems have been identified such as lack of entrepreneurial knowledge conceptually, lack of courses for entrepreneurship in schools, lack of entrepreneurial opportunities, and insufficient information about the entrepreneurship incentives and training outside the school.
\end{abstract}

Keywords: Entrepreneurship, Opportunities of Entrepreneurship, Training, Incentives of Entrepreneurship.

\section{Girişimcilik Fırsatlarının Tanımlanması}

Öz

Bu çalışma girişimcilik firsatının tanımlanması ve üniversite öğrencilerinin girişimcilik firsatları, teşviki ve eğitimi konusunda algı ve bilgisini ölçmeyi amaçlamaktadır. Bir nitel çalışma olarak yapılan bu araştırmada toplamda 32 öğrenci ile mülakat yapılmıştır. Bu öğrenciler 4 ayrı bölümden ve her bölümden de 8 öğrenci seçilmiştir. Araştırmanın sonucunda, öğrencilerde kavramsal girişimcilik bilgi eksiği, üniversitelerde yetersiz girişimcilik kursları eksiği, yetersiz bilgi paylaşımı ve okul dışında girişimci teşvik ve eğitimi konusunda yetersiz bilgilendirme gibi temel sorunların olduğu belirlenmiştir.

Anahtar Kelimeler: Girişimcilik, Girişimcilik Fırsatları, Girişimcilik teşviki, Eğitimi

* Research Asistant, Kırklareli University, Faculty of Economics and Administrative Sciences, Labor Economics and Industrial Relations, byrmblc@gmail.com 


\section{INTRODUCTION}

An entrepreneur is someone who organizes, manages, and assumes the risks of a business or enterprise. An entrepreneur is a delegate of alteration. Entrepreneurship is the process of finding out new ways of compounding sources. When the market value generated by this new combination of sources is greater than the market value these resources can produce elsewhere individually or in some other integration, the entrepreneur makes a gain.

The most explicit example of entrepreneurship is the starting of new businesses. On the other hand, in economics, entrepreneurship compounded with land, labour, natural resources and capital can generate profit. Entrepreneurial spirit is characterized by innovation and risk-taking, and is an essential part of a nation's ability to achieve in an ever alteration and increasingly competitive global marketplace.

The entrepreneur is in a widespread manner seen as an innovator - a designer of new ideas and business processes. Management skill and strong team building talents are often perceived as essential leadership attributes for successful entrepreneurs. Political economist Robert Reich takes into consideration leadership, management skill, and team-building to be main qualities of an entrepreneur.

There are some theories about entrepreneurship opportunity identification and development. One of those theories is Dubin's Theory Building. Dubin's methodology comprises eight phases. The first four parts of Dubin's model describe structural components, and the last four parts describe experiential substantiation process.

This research is aimed to make a qualitative research on the identification and exploitation of entrepreneurial opportunities over the fourth-grade students at Faculty of Economics and Administrative Sciences in Kırklareli University. Interviews such as; students concept of entrepreneurship, determination of entrepreneurial opportunities, in what level they are informed about entrepreneurship, and the impact of personal characteristics and social ties on entrepreneurs will be analyzed to try to obtain the results.

\section{IDENTIFICATION OF ENTREPRENEURIAL OPPORTUNITY}

The word "entrepreneur" gets out a thirteenth-century French verb, entreprendre, and meaning "doing something" or "to embark." By the sixteenth century, the noun form, entrepreneur, was being used to mention to someone who embarks a business initiative. The first academic use of the word by an economist was likely in 1730 by Richard Cantillon, who described the alacrity to bear the personal financial risk of a business initiative as the describing characteristic of an entrepreneur (Sobel, 2008).

Ardichvili et al. (2003) defined entrepreneurship opportunity as to designate an aspect for individuals who want to create business opportunity in anticipated attempt. While parts of opportunities can be "identified," opportunities have been made, not came across. Shane \& Venkataraman (2000) stated that entrepreneurship is a process which includes evaluation, exploitation of opportunities, and the identification.

The most significant talents of a prospering entrepreneur are to identify and select the right opportunities for new commercial enterprise (Stevenson et al., 1985). Accordingly, 
Venkataraman states that to interpret the finding and developing of opportunities is a one of the most delicate part of entrepreneurship research (Venkataraman, 1997). In the past, economists investigated inform of process by entrepreneurs. Nowadays, it is correlated with trouble shooting and giving a decision (Simon, 1967, 1991), innovation (Schumpeter, 1934), opportunity identification and the entrepreneur's alerting (Kirzner, 1979).

Opportunity is thought as the mainstay around which the assurance of entrepreneurship investigates is to be reinforced (Shane \& Venkataraman, 2000). As a matter of fact, there is a powerful field which is different from economics, strategic management and other social science disciplines as a consequence of that a better understanding of how individuals meet the opportunities (Venkataraman, 1997). As the experimental search of entrepreneurship progresses, raising amount of scholarly persons are bring to a conclusion that opportunity identification substitutes for the most characteristic and principle entrepreneurial behaviour (Gaglio, 1997a; Kirzner, 1979; Stevenson and Jarillo, 1990; Venkatamen, 1997).

According to Ardichvili (2003), a prospering opportunity development period is dependent to create a successful commercial enterprise. This involves identification of an opportunity, its valuation, and developing per se. The development period is cyclic and reiterative: an entrepreneur is likely to direct appraisals many times at different phases of developing; evaluation can also guide to identification of extra opportunities.

\section{THEORETICAL FRAMEWORK}

This section describes the most important parts of entrepreneurship opportunity identification process when entrepreneurs create or start up a new commercial enterprise. Those parts represent opportunity, recognition, development and evaluation.

The part of opportunity in a broad sense, an opportunity is to see the chance to encounter needs of market, and create the combination of resources to get high value (Schumpeter, 1934; Kirzner, 1973; Casson, 1982). Opportunitymight seem as an "inexactly-outlined market requirement, or it can appear underutilizedresources, and abilities (Kirzner, 1997).

Von indicates that the follow up opportunity might involve fundamental technologies, innovations in a market which has not been determined, or thoughts for merchandises and serving. Anticipatedclients might or might not be able to give voice to their requirements, attentions, or troubles (Von Hippel, 1994). Furthermore, Ardichvili et al. (2003) states unemployed resources, alongside new technologies or abilities can proffer possibilities to make and get new value for anticipated clients, even if the accurate forms that new value will grip might be vague.

For the Opportunity recognition Hills (1995); De Koning (1999) believe that opportunity recognition seems to involve three clear processes: (1) sensation or comprehending market requirements or underutilized resources, (2) identification or exploration a "fit" betwixt specific market requirements and designated resources, and (3) creation a new "fit" between so far apart requirements and resources in the form of a business concept (Hills, 1995; De Koning, 1999). These processes describe, individually, creation, intuition, and exploration - not elementally "identification" (Christensen et al., 1989; Conway and McGuinness, 1986; Singh et al., 1999). Ardichvili et al., (2003) points out that the business concept must logically be arranged according to the perception of both the resources and the needs. However, designing of a business concept is much 
more than discovery and perception. It is important to be aware of that the business concept also should include recombining or redirecting resources in order to create and put additional value on to that currently available. Another part is that opportunity development initiate as elementary constructs that transform into more detailed as enterprisers develop them. The opportunity development process includes proactive exertions, and improving new outcome development, however, the development process makes a significant contribution to a whole business, not just goods (Pavia, 1991). We consider that the opportunity development is an on-going proactive process which is essential to the formation of an organization. In order to develop opportunities, individuals organize the ideas as detailed business plans. But the process of opportunity development is another concept which is different from opportunity recognition and identification (Ardichvili et al., 2003).

The least part is evaluation that opportunities have been assessed at each step of their developing, even if thevaluation might be unofficial or unarticulated (Timmons, Muzyka, Stevenson and Bygrave, 1987). Valuation occurs more official once resources beyond the period of a person are consigned to the developing process.The first official valuation might include a feasibility analysis, which directs the question of whether the recommended association of resources can, as a matter of fact, convey designated value. A feasibility analysis may probably evaluate whether the worth which a specific association of resources might consign will convert into financial attainment.

A feasibility analysis utilitarian anticipated beneficiary implies the presence of a commercial enterprise, yet one fundamental in form. If the business concept has not been developed yet, the business concept might be specified by a feasibility analysis based on either resources (value creation capability) or needs (value sought). This process is known as "due diligence" which is often referred to the evaluation of a complete business plan for a new business area or for restructuring an existing business area. In the process of due diligence that individuals involved in decisions in order to operate resources for any further development. At final step, investment or acquisition will perform (or have performed) "due diligence" in their evaluation (Ardichvili et al., 2003).

Figure 1. From a market need to a successful enterprise

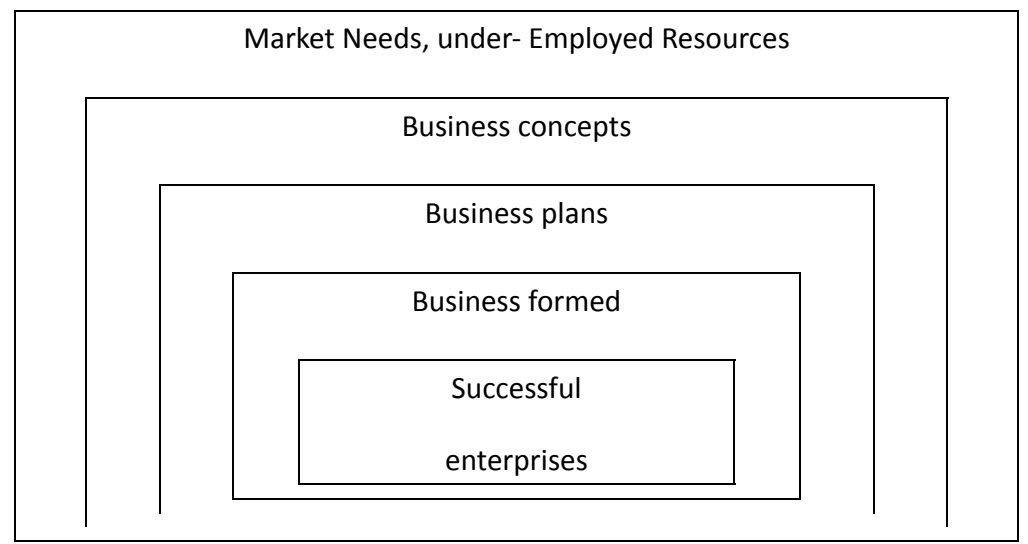

Source: Ardichvili et al., 2003. 
Ardichvili et al., (2003) totalises the opportunity, development, recognition, and evaluation of entrepreneurship in a market needs (see Fig.1). The first step is to discover the opportunity, and to understand the market needs or underemployed resources. The second step is business concept and business formed. Valuation of resources and markets conducts usable revising of business concepts. The final step is to get a successful job.

\section{EXPERIENTIAL SUBSTANTIATION PROCESS}

In this section, the last four parts that describe experiential substantiation process by Dubin's Model will be explained and those parts represent prior knowledge, personal traits, social networks and entrepreneurial alertness.

Prior knowledge is that people are inclined to give attention to information that is associated to knowledge they already know (Von Hippel, 1994). Consequently, Shane (1999) has contended that entrepreneurs will find out opportunities because prior knowledge actuatesidentification of the value of the new knowledge.Shane (1999) continues that any determined entrepreneur will find out only those opportunities associated to his or her prior information.

Each person's sui generis prior informationengenders a "knowledge corridor" that admits him/her to identify certain opportunities, but not other persons (Hayek, 1945; Ronstadt, 1988). Three primarymagnitudes of prior knowledge are significant to the process of entrepreneurial exploration: prior information of market-places, prior information of ways to servicemarketplaces, and prior information of customer troubles. Entrepreneurial education and experience play important roles in prior knowledge (Ardichvili and Cardozo 2000).

Personal traits are defined two characteristic properties. First, the connecting between hopefulness and superior opportunity identification has been sighted by a certain number of research workers. Searches by Krueger and Dickson (1994) and Krueger and Brazeal (1994) indicate entrepreneurial optimism is associated to self-efficacy faiths. It is important to signalize that hopefulness about one's capability to accomplishparticular, difficult objects (self-efficacy) is not associated to optimism in the sentiment of higher take chances.The othercharacteristic property is that of creativity.

Schumpeter (1934) was the first scholar/economist to state the view that successful entrepreneurs detect opportunities that other persons not perceive. Kay (1986) has brought to a conclusion that creative ingredients frolic a significant role in entrepreneurial deciding.

Social networks have had a significant role in simplifying the process of opportunity identification (Mot, 2011). Hills et al. (1997), bring forward "that entrepreneurs who have enlarged networks recognizeimportantly more opportunities" than individual entrepreneurs.

Granovetter's study (1973) about the strength side of weak ties showed that weak ties are not always contained in an individual's strong-tie network but also they are bridges to information resources. Mot (2011) states weak ties involve temporal acquaintanceship, and powerful ties involve those people who are our friends and family. Social communication network is the network of entrepreneur in business settings. 
Characteristic properties are the personalities and traits of the entrepreneur recognizing business opportunity. The term of "alertness", the first used by Kirzner (1973), was defined entrepreneurial identification of opportunities (Mot, 2011). Entrepreneurs who are successful have had parent levels of entrepreneurial alertness. Timmons and Spinelli (2004) have offered that successful entrepreneurs get possession of potential to see opportunity when the other people do not recognize it.

Level of entrepreneurial alertness is associated to opportunity identification (Ardichvili and Cardozo 2000; Kirzner 1997; Ardichvili, Cardozo, and Ray 2003; Busenitz 1996; Shane 2000). Three essential parts (prior information, social communication network, and characteristic properties) are parent related with the entrepreneurial alertness, which is the previous resource of the opportunity identification (Mot, 2011).

Alertness mentions to the alertness of entrepreneurial and commercial enterprise opportunities by persons. As it is clearly seen below ( see figure 2) that Mot (2011) states as the alertness to the business opportunities is identified by persons, the entrepreneurial opportunity identification is related with the previous information, social communication network, characteristic properties, and alertness ( see figure 2). This means that the four essential parts are main resources of the entrepreneurial opportunity identification.

\section{Figure 2. The Conceptual Model of the Opportunity Recognition}

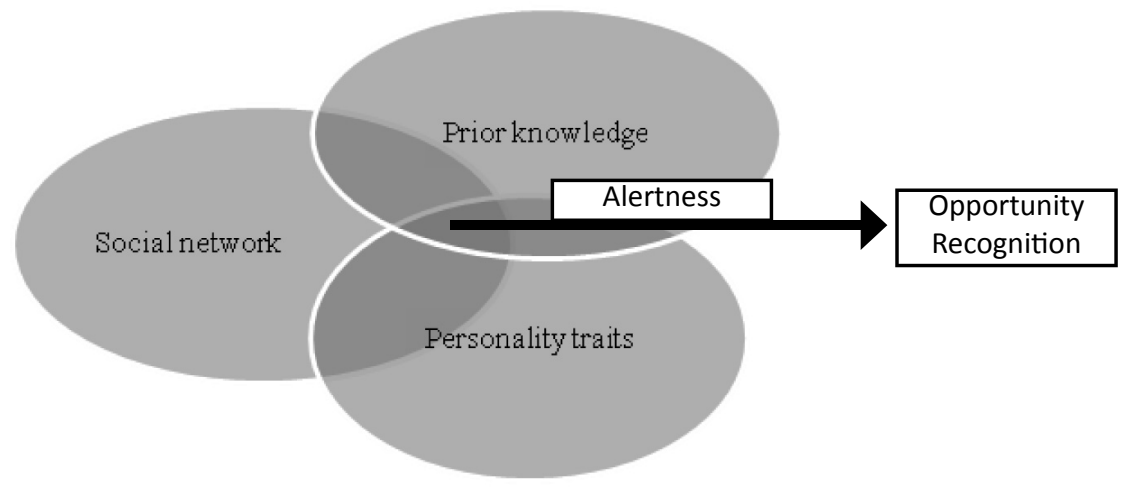

Source: Mot, 2011

\section{RESEARCH METHODS}

University of final year students' the concept of "entrepreneurial" knowledge and this study aimed to determine the objectives for entrepreneurship, literature development of entrepreneurship and entrepreneurial opportunities as a result of the concept is explained identified and evaluated. Later in the framework of the scope of the study aimed to determining the selected sample universe. The study identified constraints and Kırklareli University, Faculty of Economics and Administrative Sciences (excluding Finance, Econometrics, and International Relations) students are selected as the universe. As a result of official data and record the universe has been able to determine 
exactly. Sampling, which is one of probability-based methods, are made by a simple random sampling method. Altunisik et al (2004: 130) describe that the simple random sampling method is "All the elements in the universe equal and independent manner chance of being selected ". However, when selecting the sample in order to achieve more reliable outcomes research, attention has been paid to the equal distribution. An equal number of final year students have been selected from each subjects, and also the number of gender, equal numbers in the daytime education and evening education are preferred. Results of the examination, the universe is determined as 2458 people, and to be uniform distribution, interviews were conducted with a total of 32 students.

\section{Table 1. Frequency Distribution of Interviewed students}

\begin{tabular}{llllll|} 
Subject & Woman & Man & $\begin{array}{l}\text { Daytime } \\
\text { Education }\end{array}$ & $\begin{array}{l}\text { Evening } \\
\text { Education }\end{array}$ & Total \\
$\begin{array}{l}\text { Labor Economics and } \\
\text { Industrial Relations }\end{array}$ & 4 & 4 & 4 & 4 & 8 \\
Economics & 4 & 4 & 4 & 4 & 8 \\
Business Administration & 4 & 4 & 4 & 4 & 8 \\
Public Administration & 4 & 4 & 4 & 4 & 8 \\
Total & $\mathbf{1 6}$ & $\mathbf{1 6}$ & $\mathbf{1 6}$ & $\mathbf{1 6}$ & $\mathbf{3 2}$ \\
\hline
\end{tabular}

In the study, data collection techniques as interviews / interview method were used. In research on social sciences too often the preferred interview / interview in the primary target, comparing the data each obtained from all subjects participating in the study reveal both differences is to identify both common aspects (Yıldırım and Şimşek, 2008: 22). Face to face interviews with the students prepared set of questions open-ended questions over the orienting responses were recorded. During the interviews recording devices are used within the knowledge of participants. Responses to the questions of the interviewer then examined and coded phrases. This encoding through "content analysis" was done to try to get results. Essentially content analysis, by examining the relationships between concepts, aims to explain the raw data obtained from the results of the negotiations. Content analysis in close together, expressions, are explained in the framework of concepts and themes (Krippendorff, 2004: 18, Yıldırım and Şimşek, 2008: 227).

Table 2. Kırklareli University, Faculty of Economics and Administrative Sciences last year students' determination of entrepreneurship and entrepreneurial opportunities related problems

\begin{tabular}{|c|c|c|}
\hline Related Problems & $\mathbf{N}$ & $\%$ \\
\hline Lack of entrepreneurial knowledge conceptually & 32 & 100 \\
\hline Lack of courses for entrepreneurship in school & 28 & 87,5 \\
\hline lack of entrepreneurial opportunities & 22 & 68,75 \\
\hline $\begin{array}{l}\text { insufficient information about the entrepreneurship incentives and } \\
\text { training outside the school }\end{array}$ & 17 & 53,12 \\
\hline
\end{tabular}




\subsection{Research Findings}

Data obtained as a result of interviews were analyzed, and Kırklareli University, Faculty of Economics and Administrative Sciences last year students' determination of entrepreneurship and entrepreneurial opportunities related problems: lack of entrepreneurial knowledge conceptually, lack of courses for entrepreneurship in schools, lack of entrepreneurial opportunities, and insufficient information about the entrepreneurship incentives and training outside the school.

\subsection{Lack of entrepreneurıal knowledge conceptually}

Records of interviews conducted with students associated with the analysis lack of entrepreneurial knowledge conceptually related problems: not able to identify the concept of entrepreneurship by the participants, the lack of an infrastructure of entrepreneurship for academic or scientific knowledge, and students, trying to make a definition, are thinking as one-dimensional frame as financial means, and to be an entrepreneur needed "showing favor". It is possible to say that they have insufficient knowledge about the concept of entrepreneurship to all participants. Some students expressed within the framework of this problem area is as follows:

\section{Table 3. Conceptual Aspects of Entrepreneurship Lack of Information Related to the Problem Examples From Interview Data}

M2 "Entrepreneurship is the opportunities of evaluation for people. First of all, it must be in accordance with the character of person. I think it is relevant to be sociable and know how to talk."

M9 "Entrepreneurship is on the character of the people. For example, to investigate anything done or not in the relevant market and to take steps in this direction. For this, you need to observe your surroundings and know to go through the motions. "

M12 "Entrepreneurship is a condition associated with financial power. If you have financial strength and an opportunity arises you need to evaluate it. If you do not show yourself, no matter how much money you have you can not be a better entrepreneur. "

M22 "I think entrepreneurship is normally equality for everyone to have equal opportunity. But, in Turkey you need favor. You can not be a good entrepreneur if your back is not strong. Your chances of success are reduced. “

M34 "Entrepreneurship is primarily about Money. If you have a financial strength and the market will be various opportunities for you to shut up against the absolute best you can. So, entrepreneurial spirit reveals financial means and person traits to come together. "

M38 "I would say the opportunities and possibilities that can be encountered in life is to assess the financial aspects of entrepreneurship. To do that, you first need courage. To avoid taking risks is essential for a good entrepreneur. " 


\section{ASSESSMENT}

In a literature search on the concept of entrepreneurship it is seen as close to each other definitions. The first definition is known for entrepreneurship by Richard Cantillon. Cantillon states that "the term entrepreneur, which most people recognize as meaning someone who organizes and assumes the risk of a business in return for the profits" (Wilken, 1979: 10). However, Kırklareli University, Faculty of Economics and Administrative Sciences last year students' definition for entrepreneurship shows that they do not have enough academic or scientific knowledge for "the concept of entrepreneurship". Müftüoğlu and Durukan (2004: 105) stated that the reasons leading to failure of entrepreneurs who are making insufficient emphasis on education and ignorance. In particular, students who want to become entrepreneurs receive adequate training on this issue and it is important in terms of access to the necessary knowledge to be successful. Training will be given in the academic and scientific level in this regard, seminars and meetings to be organized is important to raise the awareness level of entrepreneurs.

\subsection{Lack of courses for entrepreneurship in school}

Records of interviews conducted with students associated with the analysis lack of courses for entrepreneurship in school related problems: lack of entrepreneurshiprelated courses, not be carried out enough information about other courses in entrepreneurship, and not enough the number of teachers in this regard. 87,5\% part of respondents emphasized the lack of courses at school for entrepreneurship. Some students expressed within the framework of this problem area is as follows:

\section{Table 4. Lack of the Course towards Entrepreneurship at school Related to the Problem Examples from Interview Data}

\footnotetext{
M17 "No. We have no course about entrepreneurship and not made any notification in this regard."

M24 "I think there is an elective course about it in the business administration, but as far as I know, neither our department nor no entrepreneurship courses in other departments. "

M33 "We do not have entrepreneurship course. They have had these courses in other schools. I think we do not have any more teachers to guide us in this regard. "
}

\section{Assessment:}

The first problem area being linked together, it is emerging as a state school and the curriculum is more related to the lack of courses for entrepreneurship in schools. Tezcan and Silver (2008: 12-15) In a study conducted by the preferences of university students on elective courses, the students' course selections were found to consider the future business life. When determining the required and elective courses at the university curriculum, it is possible to say that students should consider their thoughts for the future. Mandatory or elective courses take place in the list of courses on entrepreneurship in connection with the first problem area will help the students achieve academic and scientific level sufficient for entrepreneurship. 
Also in terms of influencing the preferences of students for life after school and it is possible to say that the importance of entrepreneurship related courses take place in the curriculum.

\subsection{Lack of entrepreneurial opportunities}

Records of interviews conducted with students associated with the analysis Entrepreneurial opportunities related problems: lack of entrepreneurial opportunities in the city where they live, the emergence of large companies and organizations across the entrepreneur is very risky, and does not find sufficient support in financial terms. $68,75^{\prime}$ lik\% of the participants have emphasized the lack of opportunities and to promote entrepreneurship. Some students expressed within the framework of this problem area is as follows:

\section{Table 5. Lack of entrepreneurial opportunities Related to the Problem Examples From Interview Data}
M4 "I live in a small town. Most of my friends at school they live in a small town like me. In general, the facilities were limited and I do not think I'm too much of a chance for people in entrepreneurship with low expectations. "
M15 "I do not know exactly, but I do not think there are probably a few institutions outside entrepreneurs and everyone knows that entrepreneurship is encouraged by the state. I am not mistaken there is support of institutions such as KOSGEB and ISKUR, but it can not reach everyone to benefit from this support, and I think it's the harsh conditions. "
M26 "There are many strong firms on the market. What can be done with a small capital against institutions operating in almost every field? "

\section{Assessment:}

Final year students are primarily due to the lack of information on this subject. Lack of knowledge can bring a one-sided point of view, as previously mentioned, and The concept of entrepreneurship can lead to reduced to a single variable. Disclosures to be made about entrepreneurial opportunities and incentives to change students' perspectives on the concept of entrepreneurship will be an important application. Bozkurt et al (2012: 13), study conducted in Turkey, while the government encouraged the forefront of increasing the points of the number of entrepreneurs, trade chambers and banks as institutions that financial incentives were found to be important. Result in the necessity of protection is another interesting point. Another important aspect for students is informing them about the possible ways of accessing about financial incentives and priority of university students about their access to financial incentives will make them more sensitive to the opportunities that will come against.

\subsection{Insufficient information about the entrepreneurship incentives and training outside the school}

Records of interviews conducted with students associated with the analysis insufficient information about the entrepreneurship incentives and training outside the school related problems: They did not receive adequate information in this regard from the government agencies, and the lack of promotional meetings and activities related 
to entrepreneurship. $53,12^{\prime}$ lik\% of the participants have emphasized insufficient information about the entrepreneurship incentives and training outside the school. Some students expressed within the framework of this problem area is as follows:

Table 6. Insufficient information about the entrepreneurship incentives and training outside the school Related to the Problem Examples From Interview Data

M8 "We went to the municipality to get information about an acquaintance and promote entrepreneurship education. But ultimately it is satisfying everyone was directing us to a place we did not get any information. We want to discuss with KOSGEB. They said that they talked a bit and opened in entrepreneurship training in specific periods. The necessary information we were told that we can participate in courses and training, but made individually sufficient information."

M16 "I think that entrepreneurship should be a very important issue and more promotional activity. However, neither the government nor the private sector do not have enough activity in the market in this regard. I think it is insufficient to achieve those made on behalf of the public."

M31 "Sufficient information is not already being done at the school. How can we be entrepreneurs if we do not get enough information outside of school?

An important part of this work already materiality. The more informed people who do not have materiality and need encouragement, but I think we're missing it. "

\section{Assessment:}

Interviewed by university student, there are both government agencies and private organizations outside the school should be pointed out that several spots about the lack of training and information activities. Bozkurt et al (2012: 13) Another result of the remarkable work they do in Turkey in the most important ways to increase the number of entrepreneurs that now is the emergence of training and the enhancement of knowledge. Education is important, as in every area of entrepreneurship. People with entrepreneurial skills and understanding can be gained through entrepreneurial training (Agca, 2007: 173). Students will be informed as to the activities and training sessions for the seminars, students gain awareness of entrepreneurship and will be significant in uncovering the potential in them.

\section{RESULTS AND DISCUSSION}

In the literature, although different from each other, again closely defined in each enterprise and entrepreneurial thinking, entrepreneurial opportunity can be assessed in different ways among different social groups and status. The concept of entrepreneurship of university students with entrepreneurial ideas and perspectives are shaped in the framework of socio-cultural and economic terms and in their own social groups.

The present study examined the issues, and it reveals that students have sufficient information on the concept of entrepreneurship. 
Due to the lack of institutional and individual information, students negatively affect their perspectives on entrepreneurship, and it also leads them to move away from this area. Considering the problem areas associated with each other seems to be inadequate training and insufficient knowledge on the basis of them. Compulsory and elective courses should be added to the curriculum in connection with the entrepreneurial part of the students in school will be useful in curbing the lack of information from at least institution.

It is also important to get information for students from outside of school entrepreneurship classes, training and increasing the number of activities of public institutions, and private sector. The university management of such organizations into contact with academic staff will organize seminars, panel discussions and training, both organizations to reach students is important in terms of easier access to institutions of both the students about entrepreneurship.

Another problem area is the lack of incentives and entrepreneurial opportunities are also emerging as a lack of knowledge. But it can say that the main reason for this is the lack of personal information. Because of the development of entrepreneurial opportunities, identifying and evaluating the personal property is subject to many variables, but is also relevant. Training will be given and disclosures will be made in this regard, people will allow them to see their potential and will allow them to see the right opportunities. 


\section{REFERENCES}

Ağca, V. (2007). Avrupa Birliğinin Girişimcilik Politikası ve Türkiye'ye Yansımaları. Ed. Kurt, M. ve Bayraktaroğlu, S., Türkiye'de İşletmecilikte Yeni Perspektifler, Gazi Kitabevi, Ankara.

Altunışık, R., Coşkun, R., Bayraktaroğlu, S., ve Yıldırım, E. (2004). Sosyal Bilimlerde Araştırma Yöntemleri, SPSS Uygulamalı. Sakarya Kitabevi, Sakarya.

Ardichvili, A., \& Cardozo, R. (2000), A Model of the Entrepreneurial Opportunity Recognition Process. Journal of Enterprising Culture, 8 (2):103.

Ardichvili, A., Cardozo, R. and Ray, S. (2003). A theory of entrepreneurial opportunity identification and development. Journal of Business Venturing, 18(1), 105-123.

Bozkurt, Ö.Ç., Kalkan, A., Koyuncu, O., ve Alparslan, A.M. (2012). Türkiye'de Girişimciliğin Gelişimi: Girişimciler Üzerine Nitel Bir Araştrrma. Süleyman Demirel Üniversitesi, Sosyal Bilimler Enstitüsü Dergisi, Cilt 2012/1, Sayı 15, Isparta.

Buzenitz, L., (1996). Research on entrepreneurial alertness. J. Small Bus. Manage. 34 (4), 35-44.

Casson, M. (1982). The Entrepreneur, Barnes and Noble Books, Totowa, NJ.

Christensen, P.S., Madsen, O.O., \& Peterson, R. (1989). Opportunity Identification: The Contribution of Entrepreneurship to Strategic Management. Aarhus University Institute of Management, Denmark.

Conway, H.A., \& McGuinness, A. (1986). Idea generation in technology-based firms. J. Prod, Innovation Manage, 4(3), 276-291.

De Koning, A. (1999). Conceptualizing Opportunity Recognition as a Socio-Cognitive Process. Centre for Advanced Studies in Leadership, Stockholm.

Gaglio, C. M. (1997). Opportunity Identification; Review, Critique and Suggested Research Directions. in J.A. Katz (ed.), Advances in Entrepreneurship, Firm Emergence and Growth, Vol. 3, pp. 139-202.

Granovetter, M. (1973). The strength of weak ties. Am. J. Sociol, 78 (6), 1360-1380.

Hayek, F. (1945). The use of knowledge in society. Am. Econ, Rev. 35 (4), 519-530.

Hills, G., Lumpkin, G.T., \& Singh, R.P. (1997). Opportunity recognition: perceptions and behaviours of entrepreneurs. Frontiers of Entrepreneurship Research, Babson College, Wellesley, MA, 203-218.

Hills, G.E., (1995). Opportunity recognition by successful entrepreneurs: A pilot study. Frontiers of Entrepreneurship Research, Babson College, Wellesley, MA, 103-121.

Hills, G.E., Shrader, R.C., \& Lumpkin, G.T. (1999). Opportunity recognition as a creative process. Frontiers of Entrepreneurship Research, 216-227.

Kay, C.J. (1986). The Identification of Catalysts Preceding Decision Making as Described by Innovators and Entrepreneurs, University of San Francisco, San Francisco.

Kirzner, I. (1997). Entrepreneurial discovery and the competitive market process: an Austrian approach. J. Econ. Lit, 35, 60-85.

Kirzner, I.M. (1979). Perception, Opportunity and Profit. University of Chicago Press, Chicago, IL.

Kirzner, I.M. (1973). Competition and Entrepreneurship. University of Chicago Press, Chicago, IL.

Kolb, D.A. (1984). Experiential learning: Experience as the source of learning and development. New Jersey: Prentice-Hall

Krippendorff, K. (2004). Content Analysis: An Introduction To Its Methodology. Sage Publication, USA-New York. 
Krueger, N.J., \& Brazeal, D.H. (1994). Entrepreneurial potential and potential entrepreneurs. Entrepreneurship Theory Pract, 19, 91-104.

Krueger, N.J., \& Dickson, P.R. (1994). How believing in ourselves increases risk taking: perceived self-efficacy and opportunity recognition. Decis, Sci., 25, 385-400.

Mot, P. (2011). An entrepreneurial opportunity recognition model: Dublin's Theory-building framework. Waseda Business and Economic Studies, No: 46.

Müftüoğlu, T., \& Durukan, T. (2004). Girişimcilik ve KOBi'ler. Gazi Kitabevi, Ankara.

Pavia, T.M. (1991) The early stages of new product development in entrepreneurial high-tech firms. J. Prod. Innovation Manage, 8 (1), 18-31.

Ronstadt, R. (1988). The corridor principle, J. Bus, Venturing 1 (3), 31-40.

Schumpeter, J., (1934). Capitalism, Socialism, and Democracy. Harper \& Row, New York

Shane, S. (2000). Prior knowledge and the discovery of entrepreneurial opportunities. Organization Science, 11 (4), 448-469.

Shane, S. (1999). Prior knowledge and the discovery of entrepreneurial opportunities. Organ, Sci., 11 (4), 448-469.

Simon, H.A. (1967). A behavioural model of rational choice. In: Alexis, M., Wilson, C.Z. (Eds.), Organizational Decision Making. Prentice Hall, New-Jersey, 174-185.

Simon, H.A. (1991). Making management decisions: the role of intuition and emotion. In: Kelly, J., Prince, J.B., Asfort, B. (Eds.), Organizational Behaviour, 2nd edition. Prentice Hall, New-Jersey, 314-324 (Also, 1987, The Academy of Management Executive 1/1, 57-64).

Singh, R., Hills, H., \& Lumpkin, G.T. (1999). Examining the role of self-perceived entrepreneurial alertness in the opportunity recognition process. Presented at the 13th UIC/AMA Symposium on Marketing and Entrepreneurship Interface, Nice, June.

Sobel, R. (2008). Entrepreneurship. THE CONCISE ENCYCLOPEDIA ECONOMICS, http://www. econlib.org/library/Enc/Entrepreneurship.html

Stevenson, H. H., \& Jarillo, J. C. (1990). A Paradigm of Entrepreneurship: Entrepreneurial Management. Strategic Management Journal, 11, 17-27.

Stevenson, H., Roberts, M., \& Grousbeck, H. (1985). New Business Ventures and the Entrepreneur. Irwin, Homewood, IL.

Tezcan, H., \& Gümüş, Y. (2008). Üniversite Öğrencilerinin Seçmeli Ders Tercihlerine Etki Eden Faktörlerin Araştrııması. Gazi Eğitim Fakültesi Dergisi, Cilt 28, Sayı 1, Ankara.

Timmons, J.A., \& Spinelli, S. (2004). New Venture Creation: Entrepreneurship for the 21st Century. 6th Ed. New York: McGraw-Hill//rwin.

Timmons, J.A., Muzyka, D.F., Stevenson, H.H., \& Bygrave, W.D. (1987). Opportunity recognition: the core of entrepreneurship, In: Churchill, N.C., et al. (Eds.), Frontiers of Entrepreneurship Research, Babson College, Wellesley, MA.

Venkataraman, S. (1997). the distinctive domain of entrepreneurship research: an editor's perspective. In: Katz, J., Brockhaus, R. (Eds.), Advances in Entrepreneurship, Firm Emergence, and Growth, vol. 3, pp. 119-138.

Von Hippel, E. (1994). 'Sticky information' and the locus of problem solving: implications for innovation. Manage', Sci. 40 (4), 429-439.

Wilken, P. (1979). Entrepreneurship: A Comparative and Historical Study. Ablex Publishing Corporation.

Yıldııım, A., \& Şimşek, H. (2008). Sosyal Bilimlerde Nitel Araştırma Yöntemleri, Seçkin Yayıncılık, Yedinci Baskı, Ankara. 